\title{
Wiedza Boga o momencie śmierci człowieka w Epistola ad Bernardum Tomasza z Akwinu a opatrzność $w$ tomizmie analitycznym
}

\author{
God's Knowledge about moment of man's death \\ in Thomas Aquinas Epistola ad Bernardum \\ and providence in analytical thomism
}

\section{MICHAŁ ZEMBRZUSKI}

Uniwersytet Kardynała Stefana Wyszyńskiego w Warszawie m.zembrzuski@uksw.edu.pl

Streszczenie. Celem artykułu jest zaprezentowanie najważniejszych twierdzeń zawartych w ostatnim - podyktowanym tuż przed śmiercią - liście Tomasza z Akwinu do opata Monte Cassino (Epistola ad Bernardum) oraz spojrzenie na nie z perspektywy najważniejszych wypowiedzi współczesnych tomistów analitycznych. List ten zasadniczo rozstrzygał pytania dotyczące wiedzy Boga i jej nieomylności, a przede wszystkim opatrzności, która może skutecznie prowadzić do określonego z góry momentu ludzkiej śmierci. W artykule przedstawione zostaną poglądy E. Stump, B. Daviesa, S.L. Brocka, Ch. Hughesa, którzy w ramach tomizmu roztrząsają tę problematykę.

Słowa kluczowe: tomizm analityczny; wiedza Boga; opatrzność; zdarzenia przyszłe przygodne; moment śmierci człowieka.

Abstract: The aim of the article is to present the most important statement in the last - dictated before his death - letter of Thomas Aquinas to the abbot of Monte Cassino (Epistola ad Bernardum) and look at it from the perspective of the most important expression of contemporary analytical thomism. This letter basically resolved questions about the knowledge of God and its infallibility and in particular providence, which would effectively lead to a predetermined moment of human death. The article pres- 
ents the views of E. Stump, B. Davies, S. L. Brock, Ch. Hughes, who in the framework of thomistic proposition solved this issue.

Keywords: analytical thomism; the knowledge of God; providence; future contingent events; the moment of death of man.

Słynna wypowiedź Tomasza: „wszystko co napisałem wydaje mi się słomą wobec tego, co zobaczyłem i co zostało mi objawione (omnia quae scripsi videntur mihi paleae respectu eorum quae vidi et revelata sunt mihi)" ${ }^{1}$, faktycznie zapisana dopiero w materiałach przygotowanych do kanonizacji, zdecydowanie może świadczyć o tym, że niczego więcej nie dodał do swojego opus. Jednak wśród dzieł nazywanych opuscula znaleźć można faktycznie „ostatnie słowo” Akwinaty - List do Bernarda. Dziełko to zasługuje tym bardziej na uwagę, że rozwiązuje niezwykle frapujące pytanie dotyczące wiedzy Boga określającej i determinującej moment ludzkiej śmierci. Ponieważ traktuję ten list jako swoisty testament Akwinaty, jako świadectwo jego życia, rozpocznę od przybliżenia historycznego kontekstu jego powstania, by następnie przejść do jego problematyki (więcej na ten temat, a także polskie tłumaczenie Listu można znaleźć w: Zembrzuski 2014, 9-15). Dopiero wówczas możliwe będzie rozjaśnienie poruszanych w tym liście kwestii, dzięki uwagom tomistów analitycznych na temat opatrzności Bożej².

\section{Uwagi historyczne o Liście do Bernarda}

Rzeczywiście po wydarzeniach z dnia 6 grudnia 1273, po mszy w kaplicy św. Mikołaja w Neapolu, Tomasz przerwał pisanie trzeciej części Summy teo-

1 Liber de inquisitione super vita et conversatione et miraculis fratris Thomae de Aquino, ed. M. H. Laurent, Neapoli 1937, 277.

2 Opatrzność (providentia) występuje w dziełach Tomasza w wielu znaczeniach. Zasadniczo stosowana jest do rozumnego działania bytów osobowych - Boga i stworzeń (aniołów w tym również demonów - a także ludzi). W przypadku opatrznościowego ludzkiego działania, jest ona jedną z części roztropności, łącząc działanie intelektu i woli, w pragnieniu ostatecznego celu i uporządkowaniu wszystkiego względem niego (S. th. I, q. 22, a. 1 co, ad 3). Akwinata problem opatrzności Bożej omawia w głównych swoich dziełach: Super Sent. I, d. 39, q. 2, a. 1-2; De veritate, q. 5, a. 1-10; Scg III, 71-77; S. th. I, q. 22, a. 1-4; Compendium theologiae a. 130-143. 
logii poświęconej sakramentom. Kolejne wędrówki i zmiany miejsca, które miały służyć polepszeniu jego samopoczucia, nie przyniosły odpoczynku, a decyzja o wyruszeniu na zwołany w Lyonie Sobór i sama podróż raczej pogorszyły jego fizyczny stan zdrowia. Zanim Tomasz dotarł do opactwa Fossanova, ostatniego miejsca w jego ziemskiej pielgrzymce, zatrzymał się jak podaje J.-P. Torrell - w miejscowości San Germano, w pobliżu słynnego opactwa benedyktyńskiego, do którego w młodości wstąpił. W miejscowości tej czekał na niego wysłannik, posłany przez opata benedyktynów z Monte Cassino, Bernarda Aygliera, który przekazał mu jego list i zaproszenie do odwiedzenia klasztoru. Ponieważ dla Tomasza, w jego ówczesnym stanie, nadłożenie 9 kilometrów drogi (w tym 480 metrów w górę) stanowiło wyzwanie, odpowiedział listownie, dyktując zapewne Reginaldowi swoje słowa (Torrell 2008, 340-341). List się oczywiście nie zachował, a osoby, które były zainteresowane rozwiązaniem tego problemu, po otrzymaniu odpowiedzi, od razu przepisały go na marginesie rękopisu tekstu „Doktora świetlistego".

Słowa Listu stanowią ostatnią z wypowiedzi Akwinaty i są żywym świadectwem jego postawy, zainteresowań, a także trzeźwego, racjonalnego (logicznego) myślenia, które nie ustały po przeżytym doświadczeniu mistycznym. I jeśli uznamy za prawdziwą „powszechną opinię”, że finis coronat opus, to ten właśnie krótki list, a nie zdanie „wszystko to słoma”, powinno być punktem odniesienia do oceny i zrozumienia poglądów filozoficznych i teologicznych Tomasza.

Obraz Akwinaty, jaki przebija z tego krótkiego listu, jest niezwykły. Z jednej strony wyraźna jest postawa pokory i obowiązkowość, a z drugiej ogromne zainteresowanie odbiorcą i chęć rozwiązania problemu. Jak wszyscy wiedzą, Akwinata w wieku 5 lub 6 lat wysłany został do klasztoru benedyktyńskiego i wprowadzany w mnisze życie aż do 15 roku życia. Oblatura dziecięca, którą przeszedł, wycisnęła piętno na jego życiu, co można dostrzec dopiero z perspektywy Listu do Bernarda. Jego pokorne odniesienie do opata klasztoru, który liczył na to, że Akwinata zaszczyci benedyktynów obecnością, wyraża się pierwszym sformułowaniu Listu, akcentującym relację syna do ojca: „Wielebnemu w Chrystusie ojcu Ber- 
nardowi, czcigodnemu z łaski Bożej opatowi Monte Cassino, brat Tomasz z Akwinu, wierny Twój syn, zawsze i wszędzie gotowy do oddania siebie z posłuszeństwem" (Tomasz z Akwinu 2014, 16). Ten zwrot może nie dziwić właśnie w kontekście relacji mnichów benedyktyńskich do swojego opata, tym bardziej że sam św. Benedykt jest określony w Liście przez Tomasza jako „nasz najświętszy ojciec”. Pozdrowienie, które zastosuje do Bernarda Aygliera na koniec Listu, nie będzie już tylko grzecznościowym zwrotem, koniecznym dla zachowania tej epistolarnej formy literackiej, ale będzie wyrażać szczere życzenia długiego zdrowia dla jego „ojcostwa”, którego piszącemu (dyktującemu) z pewnością brakuje. Należy dodać do tego również uwagę samego Akwinaty, który dostrzegł działanie opatrzności Bożej, że otrzymał list właśnie w tym miejscu i w tym momencie: „wierzę, że nie stało się to bez boskiego zrządzenia, że list Twój zastał w Akwinie mnie, podróżującego do Galii” (Tomasz z Akwinu 2014, 16).

„Gotowość do przyjścia z pomocą” oznacza dla Tomasza posłuszne oddanie swoich zdolności na rzecz zrealizowania polecenia. Tomasz mówi wyraźnie, że chciałby żywym słowem rozwiązać nurtującą mnichów kwestię przedwiedzy Bożej. Tłumaczy się jednak liturgicznymi obowiązkami, które ma do spełnienia, dodając, że treść listu może być bardziej skuteczna w rozwiązywaniu problemu - słowo zapisane zostanie utrwalone dla kolejnych pokoleń mnichów (i nie tylko). Żywe zaś słowo, choć silniejsze w przekazie, mogłoby z pewnością rozwiać wszelkie wątpliwości potwierdzone obecnością autorytetu Tomasza, jednak niekoniecznie wpłynęłoby na kolejne pokolenia domagające się rozwiązania problemu wszechwiedzy Bożej. Tomasz przebywając w opactwie Fossanova, miał zdaniem biografów skomentować cystersom Pieśń nad Pieśniami. Jednak nikt nie spisał jego lekcji, przez co potomni mogą wyłącznie snuć domysły na temat tego, co stanowiło treść jego wypowiedzi (Zembrzuski 2014, 10-11).

Akwinata na koniec listu dodaje uwagę, że gdyby słowa przekazane obecnie nie były wystarczające, to będzie gotowy do ponownego rozważenia tematu i odpisania listownie. Posłuszeństwo wyrażone w zakończeniu listu jest wręcz podwójne: posłuszna odpowiedź i posłuszna gotowość do zbudowania kolejnej odpowiedzi, jeśliby zaszła taka potrzeba. Posłuszeń- 
stwo, o którym wspomina (i wyraża w całym liście), ukazuje go jako człowieka, który z pokorą traktuje swoją pracę „opiniowania” różnych tematów, $\mathrm{z}$ jakimi się do niego zwracano. A jest to świadectwem pełnego zainteresowania odbiorcą, a także tematem, który jak się wydaje, również dla Tomasza był ważny. Nie przypadkiem Tomasz w treść listu wplata fragment dyskusyjnego tekstu, który wśród czytelników budzi nieporozumienia i błędy. Jak sam pisze: „Aby zaś zupełnie zadowolić tych, którzy wątpią, niech będą teraz wplecione [w list] słowa świętego Grzegorza, które wśród ignorantów powodują wątpliwości i błędy" (Tomasz z Akwinu 2014, 17).

\section{Problematyka Listu do Bernarda - Boża przedwiedza, wiedza i opatrzność względem działań człowieka i przyszłych rzeczy przygodnych}

Główny problem listu napisanego przez Tomasza na kilka dni przed śmiercią dotyczy interpretacji słów wypowiedzianych przez św. Grzegorza w księdze XVI jego Komentarza do Księgi Hioba (Moralia). Padają tam słowa, które rzeczywiście mogą budzić sprzeczną interpretację: „Wszechmogący Bóg przewidział z wyprzedzeniem dla każdego czas śmierci, w którym skończy się jego życie, i nikt nie może umrzeć w innym czasie niż w tym, w którym umiera” (Grzegorz Wielki 2007, 299). Z jednej strony, zdanie to zakłada istnienie absolutnej wiedzy Boga, a w związku z tym wiedzy nieomylnej, która dotyczyłaby wszystkich rzeczy przypadkowych, które mogą się zdarzyć bądź nie. Przy takim założeniu futura contingentia, a więc wszelkie wydarzenia przyszłe przygodne, mogą utracić swój charakter, gdyż byłyby z góry przewidziane, przez co z powodu nieomylnej wiedzy Boga, zyskiwałyby konieczny charakter. Z drugiej strony, w tym samym fragmencie Moraliów wspomniany zostaje biblijny przykład Ezechiasza, którego data śmierci została zarówno ustalona i przewidziana przez Boga, ale jednocześnie przesunięta o piętnaście lat, ze względu na jego nawrócenie. „Jeśli wspomina się o tym, że Ezechiaszowi zostało dodane piętnaście lat życia, to przecież ten czas życia został zwiększony względem tego, w którym Ezechiasz zasługiwał na śmierć" (2 Krl 20, 6; vide Iz 38, 5). Oznaczałoby to zatem, że chwila śmierci 
człowieka, nawet gdyby była z góry przewidziana Bożą wiedzą i realizowana Bożą opatrznością, mogłaby być z jakichś względów przesunięta na wcześniejszy bądź późniejszy termin. A przecież sugerowałoby to zmienność Bożej wiedzy i nierealizowalność opatrzności. Wolny wybór człowieka, który zostaje podjęty nie tylko z powodu samych chęci, ale także ze względu na swoją rozumną naturę, powinien w tym kontekście albo zostać usunięty, albo nie powinien podlegać Bożej wszechwiedzy i opatrzności.

Kwestia zatem dotyczy wprost, wielokrotnie podejmowanego przez Akwinatę, problemu pogodzenia wolnej woli człowieka i Bożej przedwiedzy (zob. Gałaj 2012, 77-90). On sam w Liście do Bernarda formułuje tę sprzeczność następująco: „Nie mogą bowiem te dwie sytuacje występować jednocześnie: (1) Bóg z góry wie, że ktoś umrze w jakimś czasie; (2) i umiera on w czasie innym” (Tomasz z Akwinu 2014, 18). Sprawę relacji między podleganiem czemuś w sposób wolny czy konieczny, a wiedzą Boga, rozpatruje Tomasz niejako z dwóch poziomów - samego człowieka oraz Boga. Rozróżnienie płaszczyzn może zdaniem Akwinaty pozwolić na rozwiązanie pozornej sprzeczności pojawiającej się między nimi.

Akwinata najpierw rozważa problem konieczności związanej z człowiekiem. Człowiek jest istotą tylko w pewnym zakresie ograniczoną koniecznościami (np. podlega determinacji fizycznej). Za ograniczeniem części, nie musi iść ograniczenie, a więc i podleganie całości bytu ludzkiego. Człowiek zatem z konieczności nie podlega zdarzeniom, które się jemu przytrafiają, a przynajmniej w obrębie wolnego wyboru. Jednocześnie to, co mu się zdarza, niekoniecznie musi być niekonieczne, a więc niekoniecznie musi oznaczać dla niego całkowite podleganie losowi, czy też fatum. To zatem, co dokonuje się wbrew ludzkiej woli, a mówiąc szerzej, wbrew samemu człowiekowi, to nie musi oznaczać niekoniecznego, a więc niewolnego działania w sensie absolutnym. Śmierć człowieka, która dokonuje się wbrew woli człowieka, jest przykładem takiego stanu, który nie podlega wolnej woli człowieka, jest związana z koniecznością, ale jednocześnie podlega opatrzności Boga, a więc i Jego woli. To jednak odniesienie jest różne od patrzenia na człowieka samego w sobie, który jest istotą podejmującą działania hic et nunc, a więc przygodnie. $\mathrm{Z}$ tego względu przecież, a więc 
przypadkowo, nagle, w sposób „nieuprzyczynowany”, może umrzeć. Nawet jeśli to odniesienie jest różne od tego, związanego z rozważaniem człowieka samego w sobie, to z pewnością doprowadza do tej drugiej perspektywy. Jeśli jest wiele działań i zdarzeń wymykających się konieczności, to jednak wiążą się z koniecznością z perspektywy opatrzności Bożej.

Konieczność absolutna (necessitas absoluta), o której mówi Akwinata w Liście, polega na tym, że to, co się dzieje w związku z nią, nie może zdarzyć się inaczej. I to jest konieczność, której podlega człowiek, gdy na przykład siedząc na fotelu w danym czasie, nie może na nim nie siedzieć. Konieczność warunkowa (necessitas conditionalis) polega na tym, że to, co się dzieje, dokonuje się z jakiegoś powodu, pod jakimś względem, np. że ktoś o tym wie. Człowiek wie, że siedzenie na fotelu skończy się w momencie, w którym podejmie działania prowadzące do powstania z fotela. Wiedza o działaniu, które ma za chwilę zostać wykonane, prowadzi do niego, jednak nie dokonuje się ono w sposób bezwarunkowy, absolutny. Z tej racji przecież, że mogę wstać, nie wynika, że wstaję. Zdanie Akwinaty: „z tego, iż widzę kogoś siedzącego, w żaden sposób nie wynika dla niego konieczność siedzenia” (Tomasz z Akwinu 2014, 19-20), można zrozumieć wyłącznie w kontekście zrozumienia drugiego rodzaju konieczności. Konieczność absolutna zachodzi w Bogu, ze względu na to, co jest w Nim (ze względu na to, co Jemu najbliższe), a więc nawet nie ze względu na jakieś skutki zewnętrzne i wywoływane. Konieczność warunkowa zachodzi w Bogu, ze względu na odniesienie do tego, co jest przez Niego uprzyczynowane - chcenie i wiedza o czymkolwiek z rzeczy stworzonych ma charakter konieczności warunkowej, ale nie bezwzględnej. Oczywiście, jeśli Bóg chciał i chce tego, co zaistniało, to niemożliwe jest aby tego nie chciał, gdyż jego wola pozostaje niezmienną, ale w sposób uwarunkowany (Paluch 2003, 228-231). Inaczej mówiąc, konieczność, jakiej podlega człowiek z powodu opatrzności Bożej, jest koniecznością warunkową - konieczny jest warunek, że Bóg zna z góry datę śmierci człowieka.

Wieczność, w której funkcjonuje Bóg, zakłada poznanie i wiedzę w teraźniejszości zarazem o wszystkim, co przeszłe teraźniejsze i przyszłe. Z tego właśnie względu, Bóg nie może wiedzieć o tym, że ktoś umrze w danym czasie, a on umarłby w innym. Poznanie ludzkie tymczasem, ze 
względu na temporalne zorientowanie, a więc ze względu na pamiętanie przeszłości, aktualną znajomość tego, co teraz i przewidywanie tego, co przeszłe, nie obejmie wszystkiego, zanim nie dokona się poznanie każdego kolejnego etapu. Akwinata w swoim liście bardzo wyraźnie i chętnie podkreśla ten „teraźniejszy”, „aktualny” charakter poznania Bożego, tak jakby chciał w ogóle usunąć z przypisywania Bogu kategorii czasowych. Wieczna wiedza Boga, a więc i przedwiedza i opatrzność, pozostaje do wszystkich rzeczy w teraźniejszości. Bóg ma wieczną wiedzę o zdarzeniach, które człowiek określa jako przyszłe (Tkaczyk 2015, 216-217).

Człowiek z całą pewnością może umrzeć w różnym czasie, a jego śmierć może być wynikiem ciągu przyczyn, które splatają się w wydarzenie zupełnie przez nikogo niezamierzone. Przypadkowość zdarzeń przyszłych jest poznawana przez Boga nieomylną wiedzą w Jego teraźniejszości, jednak Jego wiedza nie powoduje ich, gdyż są właśnie przypadkowe. Powodują je bowiem własne, różnorakie, niekonieczne przyczyny. Tomasz rysuje niemalże drastyczną perspektywę: „Któż bowiem nie wątpi, że mógłby wcześniej skończyć życie [będąc] przebitym włócznią, być spalonym przez ogień lub spadając z wysoka czy wpadając w pułapkę?” (Tomasz z Akwinu 2014, 18).

Zasadniczo więc data śmierci, choć jest znana Bogu i określona przez Jego przedwiedzę, to jednak z naszej perspektywy nie jest ona w przyszłości określona jako konieczna. Nie jest więc tak, że Bóg wie coś na temat wydarzeń związanych z przyszłością i one mogą się nie zdarzyć. Nie jest w związku z tym również tak, że z powodu Bożej wiedzy o przyszłości, która dla Niego funkcjonuje w teraźniejszości, wydarzenia stojące przed człowiekiem jako przyszłe, z konieczności muszą nastąpić w tym, a nie innym czasie. Jest to zagadnienie konieczności czasowej, która implikuje przeszłość jako nieodwracalną, teraźniejszość jako otwartą ale i determinującą, a przyszłość jako niezdeterminowaną (zob. Tkaczyk 2015, 38-47). Dla Tomasza więc nie ma sprzeczności między koniecznością przedwiedzy Bożej a wolnością zdarzeń (zob. Łukasiewicz 2014, 72-75). Konieczność wiedzy Bożej oznacza jej pewność na sposób, którym Bóg zna rzeczy jednostkowe, w tym te, które w porządku czasowym dopiero się wydarzą. Wydarzenia przypadkowe, przy stwierdzonej konieczności wiedzy Bożej na ich temat, pozostają 
nadal przypadkowe (kompatybilizm). Nie ma zatem determinizmu, który by występował, gdyby konieczność wiedzy Bożej oznaczała wykluczenie przypadkowości z przedmiotu tej wiedzy (zob. Olszewski 2001, 674-675).

\section{Tomiści analityczni o Bożej opatrzności i Bożej wiedzy o rzeczach przygodnych}

W ramach tomizmu analitycznego, prężnie rozwijającego się współcześnie w kręgu tradycji anglosaskiej, niemalże stałym tematem jest ustalanie sensowności wypowiedzi opisujących relacje między Bogiem, Jego wiedzą a wolnym działaniem człowieka, a także konieczną przyczynowością oddziaływania Boga a wydarzeniami przygodnymi. Oczywiście bardzo trudno jest zaliczyć jakichkolwiek filozofów czy teologów do tego nurtu tomizmu (jest to sprawa zdecydowanie umowna), jednak ze względu na charakter ich analiz i prace które prezentują, można wybrać przynajmniej czterech autorów poruszających ten temat: E. Stump, B. Daviesa, S.L. Brocka, Ch. Hughesa. Ich ujęcia charakteryzuje różnorodność podejścia do wymienionych zagadnień, a także różne sposoby prowadzonych rozważań. Jednak analiza, próby przełożenia na inny język (najczęściej sformalizowany), zwracanie uwagi na siłę argumentów oraz rozjaśnianie myśli Akwinaty za pomocą logicznego dyskursu, są dla nich w pewien sposób wspólnym mianownikiem. Ujęcia te o tyle są istotne, że świetnie wpisują się w problematykę zawartą w Liście do Bernarda. Różnicę, którą można co najwyżej dostrzec od razu, stanowi skupienie uwagi na samym problemie opatrzności Bożej, który nie zawsze jest ukazywany dokładnie w taki sam sposób jak u Tomasza. Ich ujęcia dość wiernie skupione są wokół tekstów źródłowych Tomasza, a różni ich zdecydowanie wrażliwość w analizowaniu problemów, a także odnoszenie ich do innych powiązanych problemów.

\section{a) Brian Davies - związek dobra z opatrznością}

Brian Davis porusza temat opatrzności w pracy Thomas Aquinas on God and Evil, wiążąc go z problematyką zła. Wyraźnie podkreśla, że w tym kontek- 
ście rozważania o złu są wyjątkowo chrześcijańskie. Główne zaś pytanie dotyczy tego, jak można pojąć, a nie wyłącznie banalnie zracjonalizować zło w stworzonym przez Boga świecie?

Zdaniem tego autora, mówienie o dobroci Boga u Tomasza nigdy nie jest defensywne. Tomasz nie sili się na to, by uzasadniać istnienie Boga wbrew tym, którzy mają wątpliwości co do tego, czy jest oczywiste (Akwinata przecież chętnie broni nie tylko siebie, ale i innych przed uznaniem za oczywiste istnienia Boga). Podobnie nie jest tak, że sili się na wykazanie, iż Bóg jest wystarczającym, moralnym powodem do czynienia bądź nieczynienia czegoś. Raczej Akwinata w swoim dziele robi wszystko, by wykazać, że ilość (wielkość) Bożej dobroci jest zasadniczo niemożliwa do uchwycenia. W związku z tym każda rzecz jest ze względu na Bożą dobroć poddana władzy Bożej opatrzności. Sprawa, zdaniem B. Daviesa, wygląda więc raczej tak, że akty Bożej opatrzności wystarczająco dobrze pokazują, że Boża dobroć istnieje (Davies 2011, 91).

Dla Tomasza opatrzność to „widzenie z daleka” swoista „troska” i „zarządzanie”. Jest ona istotowo treścią „widzenia zanim” i związana jest z poznaniem dobra. Jest to swoiste widzenie czegoś, zanim nastąpi prowadzenie do osiągnięcia pomyślności i uzyskania kresu. B. Davies wykorzystuje angielskie słówko provides do formułowania zdań w języku potocznym, w którym występuje opatrzność: „czy zapewniasz wszystko swoim dzieciom?” „czy masz przed oczami pomyślność swoich dzieci?”. I tak jak w ludzkim świecie jest ona nieusuwalna, tak samo, jest pełna w wymiarze Boskim (Davies 2011, 92).

Zdaniem Akwinaty - jak podkreśla B. Davies - Bóg na gigantyczną skalę potrafi zatroszczyć się i zapewnić pomyślność i dobroć wszystkiemu, co istnieje (z tego powodu uzasadnienie Tomaszowe ma metafizyczny charakter). U Tomasza wszystkie rzeczy są dobre, o ile istnieją. Wszystkie rzeczy, które istnieją (mają esse), mają to istnienie od Boga. Bóg sprawił, że istnieją wszystkie istniejące rzeczy i w związku z tym sprawił, że wszystkie jako istniejące są dobre. Postawmy pytanie, pisze Davies: „czy x jest stworzonym dobrem?”. Jeśli odpowiedź będzie twierdząca, to będzie to oznaczać dla Akwinaty, że: „x jest dobrem stworzonym przez Boga”. Nie oznacza to tego, 
że Tomasz bierze zdanie „Bóg jest dobrem” jako zdanie mówiące, że Bóg sprawia, że rzeczy są dobre (augustynizm). Raczej sądzi on, że Bóg sprawia (przyczynuje) rzeczy w taki sposób, że są dobre w istnieniu (w bycie). W takim sensie Bóg jest najwyższym stwórcą istnienia i przede wszystkim najwyższym jego dawcą oraz opatrznością (Davies 2011, 92-93).

Jak podkreśla B. Davies, stworzony porządek świata, nie jest czymś, do czego stworzenia Bóg jest zmuszony. Tomaszowa odpowiedź na pytanie, czy Bóg z konieczności chce tego, czego chce, jest negatywna. To czego Bóg chce, jest konieczne bezwarunkowo, jednak nie dotyczy to wszystkiego, czego Bóg chce. Z konieczności absolutnej chce siebie (swojej dobroci). Innych zaś bytów chce ze względu na ich przyporządkowanie do Niego, jako do celu. Jest to konieczność warunkowa, gdyż zakłada to, że Bóg chce innych bytów niż On sam. Jeżeli wola jest pragnieniem dobra, to w przypadku Boga musi być ono współmierne z dobrocią. Nawet jeśli Bóg chce siebie z konieczności, to już nie chce z konieczności tego, czego pragnie z powodu swojej dobroci (Jego dobroć może być pełna i bez tego). W ten sposób zdaniem B. Daviesa Akwinata nie chciał zrównywać Bożej dobroci z hojnością czy życzliwością. Oznacza to, że Bóg jest istotowo dobry, ale nie jest istotowo stwórcą świata. Bóg jest hojny, o ile sprawia stworzoną dobroć - i w ten sposób - będzie to racją do mówienia, że Bóg kocha stworzenia. Miłość nie ma tutaj charakteru emocjonalnego i Bóg nie może być poruszony tym samym sposobem miłości przez to, co stworzył. Z Boga wyłączone zostaje to, co jest typowo ludzkie (a nawet mogłoby stanowić słabość). Te uwagi mogą zostać zrozumiane, o ile wprowadzi się do rozważań Daviesa tezę o atrybutach Boga, które różnią się w relacji do Niego samego i do świata ad extra. Zrozumiane są zresztą $\mathrm{w}$ ramach tego, co zostało powiedziane o dwojakim rozumieniu konieczności.

Co to znaczy, że Bóg kocha wszystkie stworzenia? Zdaniem B. Daviesa oznacza to, że Bóg kocha wszystko co istnieje, gdyż to, co jest, jest dobre (rzecz w takim stopniu ma istnienie, w jakim ma dobro i jest chciana przez Boga). Wola człowieka nie jest przyczyną dobroci rzeczy, tymczasem tak jest w Bogu - jak podkreśla Davies i co zostało zaznaczone - w takim sensie rzeczy są i istnieją, w jakim są chciane przez Boga. W związku z tym miłość 
jako chcenie dobra dla kogoś (jakiegoś celu) polega wśród ludzi na tym, że to dobro wzbudza miłość. W przypadku Boga - to Bóg swoją wolą sprawia rzeczy (jak pisze Akwinata w Summie teologii (S. th. I, q. 20, a. 2): „miłość Boga napełnia rzeczy dobrocią i stwarza ją w nich - amor Dei est infudens et creans bonitatem in rebus).

Jak podkreśla B. Davies, miłość Boga dotyczy wszystkich stworzeń, gdyż chce On dla wszystkich dobra (ze względu na sam akt woli Bóg kocha wszystkich tak samo). Jednak Bóg kocha niektóre stworzenia bardziej niż inne, pragnąc dla niektórych większego bądź mniejszego dobra. Ostatecznie temat opatrzności B. Davies wiąże z tematem łaski wyrażonym przez Akwinatę w postaci cnót teologicznych uzdalniających do tego, by stać się „uczestnikami natury Bożej”. W związku z tematem predestynacji podkreśla on, że funkcja opatrzności to nic innego, jak predestynacja, związana z doprowadzeniem stworzenia rozumnego do celu będącego życiem wiecznym.

\section{b) Eleonora Stump - związek opatrzności i cierpienia}

Eleonora Stump podejmuje problem opatrzności w swoim monumentalnym dziele Aquinas (Stump 2003, 455-478). Zagadnienie to zostaje postawione w kontekście cierpienia (podobnie zresztą robi w Oxford Handbook of Aquinas oraz w artykule Aquinas on the suffering of Job). Od razu należy podkreślić, że Stump, podobnie jak B. Davies, nie zamierza tworzyć teodycei, gdyż ta za bardzo akcentowałaby temat zła. Za Tomaszem pragnie nie tylko podkreślać jego dopuszczalność, ale dostrzegać dobro całości, które może być związane ze złem części.

Pojęcie Bożej opatrzności jest pochodną rozumienia Bożej dobroci. Ponieważ teoria prostoty Bożej natury jest identyczna z dobrocią, to dobroć stworzeń jest mierzona przez ich relację do Boga. Dla człowieka najwyższe dobro i ostateczne spełnienie natury mieści się w zjednoczeniu z Bogiem. Natura Boża, która poprzedza wszystkie inne natury, stwarzając je, jednocześnie zawraca wszystko do zjednoczenia z sobą. Plan, przez który zarządza życiem ludzkim, wpływając na jego charakter i porządek wydarzeń, 
również związany z osiągnięciem Jego samego, jest opatrznością. Aktualna realizacja tego planu jest Bożym zarządzaniem.

Boża opatrzność, zdaniem Stump, rozciągająca się na wszystkie rzeczy w świecie, może być wyjaśniona przez dwa przekonania (które można potraktować jako założenia wyrażające myśl Tomaszową):

1) Bóg przez swoją opatrzność prowadzi wszystkie rzeczy na świecie do ich najwyższego dobra, to znaczy do Niego samego;

2) Boża wola spełnia się zawsze (Stump 2003, 456).

E. Stump, przechodząc do zastanawiania się nad zarzutami postawionymi przeciw Bożej opatrzności, wskazuje, że można je zebrać w dwóch grupach. Pierwsza argumentuje przeciwko samemu twierdzeniu o Bożej Opatrzności; druga akcentuje to, że szczegółowy mechanizm, przez który Boża opatrzność może działać, jest zamknięty dla Boga, w znaczeniu samego zarządzania (w tej grupie funkcjonują dwa zarzuty: 1) sposób działania Bożej wszechmocy w ludzkim działaniu i zdarzeniach blokuje działanie przyczyn drugich - bądź ich brak mógłby blokować działanie opatrzności; 2) zastosowanie Bożej opatrzności do działań ludzkich niszczyłoby wolność woli). W przypadku drugiej grupy zarzutów, które podważają opatrzność Bożą, znajdują się te, związane z drugim przywołanym wcześniej przekonaniem - Boża wola nie zawsze zostaje spełniona (nawet nie tyle jest zmienna) - nie wszyscy bowiem zostaną zbawieni, nawet jeśli Bóg chce, aby wszyscy byli zbawieni (S. th. I, q. 19, a. 6, arg. 1). Ludzka wolna wola - jest również pewnym wyrazem działania podważającego spełnianie woli Bożej (Bóg daje człowiekowi wolność, z której on nie potrafi korzystać; stwarza anioła, który aktem swojej woli przeciwstawia się swemu Stwórcy).

E. Stump w następujący sposób przedstawia Tomaszową odpowiedź na zagadnienie skuteczności woli Bożej: wola Boża zawsze chce dobra, lecz czasami to, co jest rozważane jako dobre, absolutnie nie jest dobrem w danych okolicznościach i nieprzewidzianych uwarunkowaniach. E. Stump podaje niemalże klasyczny przykład matki, która kocha własne dziecko i karci je w ramach troski o jej dobro (co pozornie może wyrażać brak miłości). Przykład jest poparty sformułowaniem Akwinaty, który mówi, że to, co może się wymykać Bożej woli w jednym porządku, wraca w drugim 
(grzesznik odchodzi od Bożej woli, i wraca gdy jest karany przez Jej sprawiedliwość). E. Stump wprost wyraża zdanie: „Bóg uprzednio chce dobra absolutnego, zaś aktualnie chce dobra w okolicznościach" (Stump 2003, 457). Uprzedniość w tym zdaniu nie sugeruje zmiany, lecz związana jest z wynikającą z niej konsekwencją Bożej woli. To, co jest uprzednio chciane przez Boga, nie jest Jego właściwą wolą (w całości), lecz pewną inklinacją jego części. To, co Bóg aktualnie chce, wszystkie akty woli, które Bóg formuje, są aktami będącymi konsekwencją woli (i w takim sensie są spełnione).

Zdaniem E. Stump, wątpliwości dotyczące opatrzności mogą zostać rozwiązane, gdy tekst biblijny, mówiący o tym, że Bóg „pragnie, by wszyscy ludzie zostali zbawieni (1 Tm 2, 4)", zostanie zinterpretowany w taki sposób, że będzie dotyczył woli poprzedzającej. Chcenie tego, żeby ludzie na przykład nie żałowali swoich wyborów, do niej należeć nie będzie, lecz będzie się stosował do woli następczej (w ten sposób nie wszyscy będą zbawieni). Jakkolwiek więc, gdy ludzie grzeszą lub odwracają się od Boga i chcą czegoś wbrew Jego woli, to ich zamiar wymierzony jest przeciw woli poprzedzającej, a nie następczej, chcą tę pierwszą naruszyć (zapewne „prawdziwy grzesznik”, podpinający się pod szyld ruchu nazywanego „Nowym ateizmem”, nie tylko chciałby, żeby wola Boga się nie spełniła, ale żeby to wola dająca i obiecująca człowiekowi zbawienie się nie spełniła). Tymczasem wola następcza zawsze się spełnia (w takim względzie nie wszyscy będą zbawieni, a na pewno ci, którzy nie chcą).

Tomaszowa doktryna opatrzności, zdaniem E. Stump, „zaślubia filozoficzny i teologiczny absurd" nieuznający przypadkowości w świecie. Gdyby ktoś dzisiaj stwierdził, że nie ma przypadku w świecie, to wypowiadałby się przede wszystkim przeciw współczesnej nauce. Jeśli wola Boża spełnia się zawsze, to rzeczy przyszłe i przygodne stają się jako chciane przez Boga. Nic nie może zdarzyć się przez przypadek, a nawet więcej, cokolwiek się dzieje, dzieje się z konieczności. Taki wniosek, jaki wyprowadzić miał Akwinata funkcjonuje wbrew powszechnej opinii. U Tomasza bowiem Boża wola nie narzuca konieczności na wszystkie chciane przez Boga rzeczy jako konsekwencja Jego sprawczej woli. Ta konsekwencja rozciąga się na powodowanie chcianych skutków i dotyczy sposobu, w jaki skutki się pojawiają. 
Rzeczy się stają nie tylko dlatego, że Bóg chce, by się stały, ale stają się $\mathrm{z}$ konieczności albo przygodnie względem jego woli.

Pewne rzeczy stają się przygodnie, ponieważ Bóg przygotował przygodne przyczyny, które doprowadzają do przygodnych skutków. Na przykład przez stworzenie człowieka wraz z jego wolną wolą, Bóg sprawił przygodną przyczynę, od której zależą przygodne skutki (zależą od wolnego wyboru). W związku z tym, nawet jeśli wszystko dzieje się zgodnie z opatrznościowym planem, to nie oznacza, że rządy Boże narzucają konieczność we wszystkich rzeczach kierowanych.

E. Stump w charakterystyczny dla siebie sposób analizuje problem Hioba, korzystając z komentarza Akwinaty do tej księgi. Bardzo wyraźnie podkreśla podejście Akwinaty do Księgi Hioba, której nie traktuje jako dzieła o złu w świecie ani podejmującego tematu cierpienia niewinnej osoby, na którą patrzy wszechpotężny, wszechwiedzący i doskonały Bóg. Według Tomasza Księga Hioba akcentuje naturę działania Bożej opatrzności i jest próbą odpowiedzi na choćby takie pytania: jak Bóg zarządza rzeczywistością, czy cierpienie niewinnej osoby zmusza nas do stwierdzenia, że opatrzność Boża nie rozciąga się na ludzkie sprawy? Nie jest to tylko niewielkie przesunięcie nawet względem współczesnego odczytywania tej księgi biblijnej, lecz także zdecydowana zmiana względem generalnego sposobu odczytywania Tomaszowego rozumienia zła (vide Roszak 2013, 114-116).

Rozmowa Hioba z przyjaciółmi jest debatą nad właściwym rozumieniem opatrzności (które ma Hiob i którego nie mają jego przyjaciele). „Jeśli w tym życiu człowiek zostaje nagrodzony przez Boga za dobre czyny i ukarany za zło, jak usiłował wyjaśnić Elifaz, to w konsekwencji będzie mogło się wydawać, że najwyższy cel człowieka będzie mieścił się w tym życiu. Tę opinię zamierzał obalić Hiob i zamierzał pokazać, że obecne życie człowieka nie ma w sobie ostatecznego kresu, lecz jest porównywane do niego jako ruch do spoczynku i droga do kresu" (Super Iob, cap. 7).

To zdanie nie dotyczy czego innego jak opatrzności, która polega na prowadzeniu do celu. Oczywiście to nie jest zaskakujące, że to, co się przydarza człowiekowi może być uzasadnione i usprawiedliwione przez odniesienie do życia wiecznego, które człowiek osiąga poprzez śmierć. Z jednej 
strony, człowiek zna dobra (dotyczy to życia wiecznego), które usprawiedliwiają cierpienie. Z drugiej strony, cierpienie jest usprawiedliwieniem tylko w przypadku, w którym jest dobrem dla samego cierpiącego. Przykładem dla Stump są cnoty, które są uzyskiwane przez cierpienie (albo szerzej przez zło): cierpliwość spowodowana przez chorobę; pokora spowodowana przez doświadczenie winy i skruchę. Jest to o tyle ważny punkt, że zdaniem Stump, Akwinata w tym miejscu pragnął podkreślić opis działania Bożej opatrzności zarówno względem życia obecnego, jak i wiecznego.

E. Stump bardzo chętnie przywołuje komentarze Akwinaty do Pisma św., na temat cierpienia i dostrzegania jego sensu w życiu ludzkim i w istnieniu całego świata ${ }^{3}$. W każdym ze swoich artykułów przywołuje fragment z Komentarza do Listu do Rzymian (Super Rom., c. 8, 1. 6), który jest zresztą bardzo pasjonujący: „zło uczynione przez grzeszników przyczynia się dla dobra sprawiedliwych”. U Akwinaty nie chodzi wyłącznie o mocną tezę biblijną, ale również o mocne filozoficzne uzasadnienie tego, że wszystkie rzeczy w świecie współpracują dla istot, które będąc istotami rozumnymi, kochają i zmierzają do Boga.

E. Stump ostatecznie określa stanowisko Tomasza w sprawie opatrzności jako (wyłącznie pozornie) postawione na głowie (topsy-turvy). O opatrzności można mówić w kontekście rozumienie szczęścia (nie będącego tym, co Hiob utracił) i cierpienia, gdyż okazuje się, że w nich działa opatrzność. Jak pisze Stump: „jest to jednak dość nieludzka perspektywa, gdyż okazuje

3 Z drugiej strony przechodzi do charakterystyki cierpienia. I to akurat jest bardzo ciekawy aspekt, gdyż w bardzo konsekwentny sposób E. Stump opiera się na fragmentach Tomaszowych komentarzy do Corpus Paulinum. Główny nacisk położony jest na ideę że ból i cierpienie są Bożym lekarstwem dla „duchowego raka”. 1) Fragment z Komentarza do Credo (art. 1): „Tak więc jeśli wszelka kara, którą człowiek ponosi jest od Boga, należy ją cierpliwie znosić. Kary bowiem oczyszczają z grzechów, winnych czynią pokornymi, dobrych zaś prowadzą do miłowania Boga. Czytamy w Księdze Hioba: Dobro przyjęliśmy z ręki Boga. Czemu zła nie możemy przyjąć?”. 2) Fragment z Komentarza do Tesaloniczan: „Jak woda gasi płonący ogień, tak niepowodzenia (tribulationes) gaszą siłę pożądliwości w taki sposób, że człowiek nie idzie za nimi z chęcią [...] Kościół zatem nie jest zniszczony przez niepowodzenia, lecz podnoszony w górę, a w pierwszym rzędzie przez podnoszenie umysłu ku Bogu, jak mówi Grzegorz: zło, które nas teraz przygniata, prowadzi nas, kierując do Boga”. 3) Fragment z Komentarza do Hebrajczyków: „Wszyscy święci, którzy radują się Bogiem, przeszli przez wiele cierpień, przez które stali się synami Boga”. 
się, że działamy nie tak jak chcemy (czy też nie działamy tak jakbyśmy chcieli)" (Stump 2013, 468). Jednak zdaniem tej amerykańskiej tomistki, to raczej renesans widział w średniowieczu niehumanistyczne rozumienie świata jako tego, którego cele nie mieszczą się w nim i nie są osiągane w nim. Doskonale mają wyrażać to słowa z Tomaszowego Komentarza do księgi Hioba: „Skoro człowiek został stworzony z natury duchowej i ciała ziemskiego, to zło człowieka tkwi w tym, że opuszcza duchowe dobra, do których był przyporządkowany zgodnie z rozumnym umysłem, a przylega do ziemskiego dobra, które sobie dopasowuje według ziemskiego ciała” (Super Iob, cap. 1).

\section{c) Stephen L. Brock - opatrzność i przygodność przyszłości}

Stephen L. Brock w dziele zredagowanym pod tytułem Analytical thomism. Traditions in dialogue, podjął się ukazania zagadnienia konieczności i sprzeczności, funkcjonujących w zdaniach formułowanych na temat zdarzeń czasowych (szczególnie przyszłych, ale także i teraźniejszych). Jego artykuł jest zestawieniem koncepcji G.E.M. Anscombe i Akwinaty na ten temat i stanowi obronę Tomaszowego rozumienia wiedzy, której przedmiot, jeśli ma faktycznie posiadać cechy prawdziwości, nie może być przyszłym. Moją uwagę - w niezwykle interesującym artykule - zwróciła sama interpretacja możliwości i konieczności występowania przygodnych wydarzeń przyszłych (Brock 2006, 283-284; Anscombe 1981, 25).

Tomasz dwojako rozumiał możliwość (zaczerpnął je z Hermeneutyki Arystotelesa - Expositio Peryermeneias I, 1. 15, n. 3): (1) „to, co jest wolne od sprzeczności” oraz (2) „to, do czego rzecz jest w możności” (Tomasz z Akwinu 2013, 297-298). Pierwsze z tych rozumień posiadające absolutny charakter należy do logiki (swoista przynależność orzeczenia do podmiotu w zdaniu prawdziwym), ale może mieć - a więc i ma - zastosowanie także do realnych bytów (będzie wyrażać charakter ontologiczny). Drugie z kolei rozumienie, które jest warunkowe (ze względu na możność), ma odniesienie wyłącznie do istniejących rzeczy. Tego rodzaju możność, w metafizyce Akwinaty, będzie zasadą aktu (możność czynna) lub będzie istniała w pew- 
nym sensie pod aktem (możność bierna). Możność w człowieku jest tym, do czego jako działający lub doznający jest lub nie jest zdolny.

S.L. Brock przywołując następnie opozycje (negacje) wobec tych określeń, korzysta z Tomaszowego wyjaśnienia konieczności absolutnej i warunkowej. Konieczne absolutnie jest to, co brane jest dla rzeczy ujętej w sposób absolutny (o ile rzecz jest rozważana względem jej natury). Konieczne warunkowo jest to, co wiąże oddziaływanie czynnika zewnętrznego na naturę przedmiotu działającego (może to dotyczyć zarówno „działania w aspekcie” czy też „działania nakierowanego”) (Brock 2006, 290291). Autor ten, stosując kategorie konieczności absolutnej i warunkowej, nie stosuje ich do Boga, lecz do człowieka i jego życia i śmierci. W tym znaczeniu zyskują one inny charakter.

Posługując się mimo wszystko tymi narzędziami, omawiany autor stwierdza, że to, co jest absolutnie konieczne dla rzeczy, może być czymś, czego przeciwieństwo spowoduje sprzeczność jako niezgodność względem istniejącej rzeczy (śmierć kończy życie człowieka). Jednak może być czymś, dla czego przeciwieństwo może nie mieścić się w naturalnej możności rzeczy i w związku z tym, może nie wywołać sprzeczności (umrzeć nie oznacza zginąć na wieki). Śmierć jest bowiem czymś absolutnie koniecznym dla ludzkiego bytu, gdyż człowiek nie ma danej z natury żadnej możności (mocy), by żyć na wieki. Jednak życie na wieki nie pociąga za sobą sprzeczności. Życie wieczne, jako coś przyszłego, co może również nie nastąpić, nie jest absolutnie niemożliwe, lecz tylko nie możliwe ze względu na naturalną możność do życia, które się skończy. Tomaszowa perspektywa zakładająca wiedzę na temat przyszłego wydarzenia eschatologicznego, akcentuje to, że Bóg może uczynić życie wiecznym, przez przekazanie supernaturalnej możności do tego, by je uzyskać (Brock 2006, 291).

Jak pisze S. Brock, sens w jakim niemożliwe jest, by ślepy stał się widzącym lub by człowiek żył wiecznie, jest sensem całkowicie odpowiadającym naturalnym rzeczom. To, że Bóg może uczynić takie rzeczy, nie oznacza, by ze świata usunięta została konieczność (niemożliwość). Boża wszechmoc i opatrzność nie eliminują prawidłowości i konieczności, jakie można byłoby znaleźć choćby w arystotelesowskim universum. Konieczność w rze- 
czach nie zostaje zawieszona, gdyż nie zostaje zawieszona przygodność i dopuszczalność przyczyn wtórych. Bóg posiada moc, by działać poza koniecznością, jako powszechna przyczyna istnienia i wszystkich sposobów bytu, ale jednocześnie przekraczająca ten porządek swoją wolą (Brock 2006, 292-294).

Tomaszowe rozumienie przyszłych wydarzeń nie idzie w radykalny sposób tropem futura contingentia, wykluczając tym samym absolutną konieczność (przy czym trzeba pamiętać, że konieczność nie musi wykluczać wolnego wyboru). Stwarzając mocą woli, a więc niekoniecznie, Bóg powoduje rzeczy, które następują z konieczności bądź są absolutnie konieczne tak jak śmierć i życie wieczne. Z analiz S. Brocka wynika zatem dla naszego tematu, że przyszłość nie jest zdeterminowana jakąkolwiek koniecznością, pozostaje przygodną, a więc data śmierci jest nieokreślona. Ale jednocześnie z konieczności faktu śmierci wynika, jako niesprzeczne względem niej, możliwe życie wieczne.

\section{d) Christopher Hughes - opatrzność a przyszłe wydarzenia przygodne}

Christopher Hughes jest autorem artykułu Aquinas on God's Knowledge and Future Contingens, opublikowanego w zbiorze redagowanym przez „twórcę” tomizmu analitycznego, Johna Haldane'a: Mind, metaphysics and value in the thomistic and analytical traditions.

W swoim artykule zwraca przede wszystkim uwagę na związek zagadnienia futura contingentia z problematyką opatrzności. Stanowisko Akwinaty jest w tym względzie jasne (De veritate q. 2 , a. 12 , co), gdyż działanie opatrzności wyraża możliwość poznawania przez Boga rzeczy przyszłych i przygodnych. Gdyby Bóg ich nie poznawał, to jak pisze Akwinata, sprawy ludzkie, które są właśnie takie, nie podlegałyby opatrzności. Z kolei uznanie, że wiedza Boża dotyczyłaby rzeczy koniecznych, pociągałoby za sobą konsekwencję, że sprawy ludzkie są konieczne, przez co odrzucony by został wolny wybór.

Stanowisko Akwinaty, zdaniem Ch. Hughesa, wyraża się więc w następujący sposób: Boża wiedza o przyszłych wydarzeniach przygodnych 
jest kompatybilna z ich przygodnością (choć nie jest to także dla samego Akwinaty takie oczywiste - brał pod uwagę wiele argumentów - wyrażał je w zarzutach - pokazujących inkompatybilny charakter Bożej wiedzy z przygodnością jej przedmiotu). Ch. Hughes właściwie cały swój artykuł poświęca dwóm argumentom i Tomaszowym odpowiedziom na nie (rozważa ich sensowność i konkluzywność). Pierwszy z tych argumentów pochodzi z Summa contra gentiles (I, 63), drugi bardziej niejasny z De veritate (a. 2, q. 12, ad 7).

Odnosząc się najpierw do pierwszego z nich, trzeba pamiętać, że zdanie Tomasza wyraża uznanie tego, że Bóg poznaje rzeczy przyszłe przygodne, zarzut zaś wyraża niemożliwość istnienia wiedzy o rzeczach przyszłych. Zarzut wygląda następująco: przyszłe zdarzenia przygodne nie mogą być przedmiotem wiedzy pewnej, gdy są przyszłe; cała wiedza Boga jest pewna, Bóg nie może poznawać przyszłych „przygodników”; Bóg zresztą nie może mieć o nich wiedzy w jakimkolwiek innym czasie, gdyż w ten sposób jego wiedza byłaby zmienna. Odpowiedź Tomasza zakłada Boecjański punkt widzenia i wiedzy, która nie jest wiecznie trwała (całoczasowa), lecz bezczasowa (poza i ponadczasowa). Każda rzecz, która się zdarza w jakimkolwiek czasie, jest obecna w wieczności, nawet jeśli jest przeszła lub przyszła w odniesieniu do czasu. „Intelekt Boży ogląda w całej swej wieczności jako teraźniejsze wszystko to, co istnieje przez cały bieg czasu” (Contra Gentiles I, 66).

Jak argumentuje Ch. Hughes: „Dlatego, że bycie przyszłym zdarzeniem przygodnym i bycie zdarzeniem przedstawiającym się jako przedmiot pewnej i nieomylnej wiedzy są właściwościami inkompatybilnymi, nic nie może mieć tych właściwości w tym samym czasie. Nic jednak nie powstrzymuje przed tym, by jakieś zdarzenie miało pierwszą właściwość w jednym czasie (kiedy zdarzenie jest przyszłe) i miało drugą właściwość w innym czasie (kiedy zdarzenie jest teraźniejsze). Podobnie nic nie powstrzymuje także przed tym, by jakieś zdarzenie miało pierwszą właściwość w jednym czasie i drugą w bezczasowej wieczności Boga. Istnieją zatem przyszłe zdarzenia przygodne i Bóg posiada pewną i nieomylną wiedzę o nich - nie teraz (gdy są przyszłe) lecz w wieczności (kiedy są wiecznie obecne)" (Hughes 2002, 145). 
Autor wskazuje, że argument jest jasny, jednak nie jest przekonujący w pełnym sensie. Jest niewystarczalny, by pokazać posiadanie przez Boga wiedzy o rzeczach przyszłych przygodnych. Autor ten sugeruje, że argument powinien być uzupełniony przez rozważania o tym, że jeśli Bóg ma wiedzę o przyszłych przygodnych zdarzeniach, powinien mieć wiedzę o przyszłych przygodnych jako przyszłych. Gdyby Bóg taką wiedzę posiadał, to argument Tomasza byłby bardziej przekonujący.

Drugi argument przeciwny pojawia się w Summa theologiae (I, q. 14, a. 13) i w De veritate (q. 2, a. 12, ad 7). Zrekonstruowany argument brzmi następująco: „jeśli okres warunkowy posiada absolutną konieczność poprzednika, to posiada absolutną konieczność następnika. Okres warunkowy: jeśli Bóg wiedział, że to zdarzenie przypadkowe będzie, to ono będzie - jest prawdziwe. Co więcej, jego poprzednik jest absolutnie konieczny, skoro jest wieczny i odnosi się do przeszłości. Zatem jego następnik jest absolutnie konieczny. W ten sposób cokolwiek Bóg wie, jest absolutnie konieczne i Boża wiedza nigdy nie odnosi się do rzeczy przygodnych” (Hughes 2002, 146). Trzeba pamiętać, że użyte w tym zarzucie rozumienie konieczności absolutnej jest różne od tego, które posiada Akwinata i że w kontrargumencie zostało wykorzystane do obalenia koniecznej wiedzy Boga o rzeczach przygodnych.

Ch. Hughes referuje odpowiedź Akwinaty, w której przywołuje on różne rozumienia poprzednika w okresie warunkowym: „Bóg wiedział, że to będzie i to będzie”. Warto pamiętać o średniowiecznych myślicielach, którzy inaczej interpretowali to zagadnienie: poprzednik jest przypadkowy - Bonawentura; poprzednik jest przypadkowy, ale składa się również z koniecznego - Robert Grosseteste. Tomaszowa odpowiedź na to zagadnienie jest taka, że poprzednik jest absolutnie konieczny (albo nawet wprost konieczny).

Autor ten podaje Tomaszowe rozwiązanie przywołując również jego przykład (Hughes 2002, 147-148):

(1) Jeśli dusza poznaje coś, to to coś jest niematerialne

(1a) Jeśli dusza poznaje coś, to ta rzecz o ile jest w duszy jest niematerialna

(1b) Jeśli dusza poznaje coś, to ta rzecz, o ile istnieje w sobie, jest niematerialna (to zdanie jest fałszywe choć 1 a jest prawdziwe) 
Analogicznie do tego można wypowiedzieć zdania o wiedzy Bożej:

(2) Jeśli Bóg wiedział, że ta rzecz będzie, to jej istnienie jest konieczne

(2a) Jeśli Bóg wiedział, że ta rzecz będzie, to jej istnienie, o ile jest znane przez Boga, jest konieczne

(2b) Jeśli Bóg wiedział, że ta rzecz będzie, to jej istnienie, o ile jest w sobie, jest konieczne.

Zdanie 2 jest prawdziwe, o ile jest prawdziwe 2a, nawet jeśli fałszywe jest $2 \mathrm{~b}$.

Z tego, że Bóg wie o jakiejś rzeczy jako obecnej wynika, że jest ona jako obecna konieczna, lecz nie wynika, że istnienie rzeczy jest konieczne dlatego, że Bóg posiada o niej wiedzę.

Ch. Hughes następnie przenosi ten sam rodzaj argumentacji na różnicę jaka zachodzi między naszą wiedzą o rzeczach przygodnych, a wiedzą Boga o rzeczach przygodnych.

(3) Jeśli wiemy, że coś będzie, to istnienie tego jest konieczne

(3a) Jeśli wiemy, że coś będzie, to istnienie tego, o ile jest znane przez nas, jest konieczne

(3b) Jeśli wiemy, że coś będzie, to istnienie tego, o ile jest w sobie, jest konieczne.

Według Akwinaty obydwa uszczegółowienia są prawdziwe w ludzkiej wiedzy o rzeczach przygodnych - również jeśli dotyczy to istnienia rzeczy w sobie. Inaczej jest w przypadku wiedzy Boga - to co jest znane przez Boga, musi być konieczne jako przedmiot wiedzy, jednak nie musi być absolutnie konieczne. Według Ch. Hughesa, Akwinata zaprzecza temu, co zostało powiedziane w odpowiedzi na drugi zarzut - że to, co Bóg wie jest konieczne, nie jako przedmiot Bożej wiedzy, lecz jako coś, co jest znane w sobie absolutnie i wprost.

Autor podkreśla, że odpowiedź na zarzut 2 opiera się na następujących przesłankach: (a) fakty o których Bóg wiedział są zawsze konieczne; (b) absolutna konieczność jest zamknięta względem implikacji. Jeśli uzna się obydwa twierdzenia, wówczas nie można mieć nadziei na zaprzeczenie absolutnej konieczności o tym, co Bóg wie. Akwinata odrzuca w sposób niemy zarzut 2 i zawarte w nim dwie przesłanki. 
Dalsze rozważania Ch. Hughesa są szczegółową analizą tego, na ile wiedza Boża zawiera absolutną konieczność, czyli na ile występuje to, że kiedy Bóg wie, że Q, to wiedza o Q jest absolutnie konieczna. Jego zdaniem jeśli Akwinata ma utrzymać wiedzę o zdarzeniach przyszłych przygodnych, powinien zaprzeczyć posiadaniu wiedzy absolutnie koniecznej. Jedynym sposobem na zatrzymanie zarzutu o niemożliwości poznania rzeczy przygodnych przez Boga jest domaganie się, by absolutna konieczność nie była zamknięta na implikacje (co nie jest łatwe, biorąc pod uwagę zadanie Arystotelesa, że z koniecznych przesłanek wynikają wyłącznie konieczne wnioski).

Cały problem związany jest z zagadnieniem konieczności, które przynajmniej w omawianych tekstach posiada dwa znaczenia. Absolutna konieczność - metafizyczna konieczność (prawda we wszystkich czasach i możliwych światach). Konieczność - jako zależność od przyczyn, która powoduje skutek przy założeniu, że nic nie może jej przeszkodzić. Ten drugi rodzaj konieczności, przez Akwinatę był określany jako konieczność warunkowa.

We wszystkich tych tekstach Akwinaty (S.th., Contra Gentiles, De veritate) chodzi o konieczność jako zależność przyczynową (jeżeli Bóg wie, że coś będzie, to się to stanie). Nazywa to swoistą predeterminacją - zdarzenie jest konieczne, o ile jego pojawienie się jest zdeterminowane bądź ustalone przez jego przyczyny, przed jego pojawieniem się (poznajemy mający nastąpić wschód słońca na podstawie prawdziwej wiedzy).

Autor następnie wraca do zarzutu i zakłada, że w zarzucie chodziło właśnie o tego rodzaju predeterminację. Można założyć, że zdarzenie jest konieczne, o ile jego pojawienie jest zagwarantowane zarówno przez przeszłe bądź obecne przyczyny albo obecną historię światową (aż do współczesności). W tym kontekście również można byłoby mówić o prawdziwości konieczności tego rodzaju zdarzeń (i nawet jeśli tam była prawda, to tutaj jest dochodzenie do niej). Autor przywołuje przykład przygotowania do wycieczki do weneckiej wyspy Mazzorbo. Przez jej urzeczywistnienie, zdarzenie staje się konieczne w tym sensie, że jej nie zdarzenie jest niemożliwe. Tego rodzaju konieczność (jako pewna nieuchronność) jest wielokrotnie 
przywoływana, gdy mowa jest o futura contingentia, które stają się pewne, gdy są poznane jako teraźniejsze (Hughes 2002,149-150).

Kiedy zdarzenie jest przyszłe i przygodne - nie może być i nie być zarazem; kiedy się aktualnie pojawia - nie może już nie być. Mowa jest oczywiście o konieczności ex suppositione - o której Akwinata więcej mówi w Komentarzu do Hermeneutyki, zaś w Liście do Bernarda nazywa ją conditionalis. Przeszłość i teraźniejszość są konieczne simpliciter, dlatego że się zdarzają. To, co przyszłe ma charakter konieczny zgodnie z pewnym założeniem dostrzeżeniem predeterminujących przyczyn.

W odpowiedzi na zarzut, Akwinata nie zaprzecza, że prawdziwe zdanie „Bóg wie o tym, co nastąpi” jest zawsze konieczne. Raczej Akwinata w odniesieniu do zdarzeń przyszłych zachowuje stanowisko radykalnie nienecesarystyczne. To stanowisko, zdaniem omawianego autora, dotyczy również przeszłości i teraźniejszości - przez co Ch. Hughes odchodzi od myśli Tomasza. Jest to zresztą duży problem filozoficzny (ale również można w tym punkcie dostrzec pewną sprzeczność w wyjaśnieniach Akwinaty) - dlaczego zdarzenia, które są nieznane, kiedy są przyszłe, stają się znane, kiedy są obecne.

Hughes zwraca jeszcze uwagę na to, że problem absolutnej konieczności zawartej w zdaniu „Bóg wie o tym, co będzie” dotyczy wiecznej teraźniejszości, a więc może nie mieć związku z samym podziałem czasowym - choć jest to ponownie wbrew stanowisku Akwinaty (Hughes 2002, 151).

Autor w sposób zdecydowany poddaje w wątpliwość to, czy wszystko w Bogu jest konieczne na zasadzie absolutnej - wola Boga nie jest przecież absolutnie konieczna działając w wiecznej teraźniejszości (nie jest sprzeczna w związku z tym z jego wiedzą). Boże chcenie Jego samego (velle) ma charakter absolutnie konieczny, jednak pozostałe są konieczne z założenia (np. Bóg tak chciał).

Autor sam przyznaje, że jego odpowiedź nie idzie wprost tropem Akwinaty i jest zupełnie inna niż jego odpowiedź (tak naprawdę uznaje on, że to, co zawarte w odpowiedzi na zarzut, nie jest odpowiedzią Tomaszowa). Wszystko co się teraz zdarza nie jest konieczne absolutnie. Nie należy zgodzić się z tym, że to samo może być powiedziane o wszystkim, co dokonuje 
się w wiecznym teraz. Akwinata zaprzeczył, że wszystko co się teraz dzieje jest konieczne absolutnie, tak jak odrzucił twierdzenie, że wszystko co dzieje się w wiecznym teraz, jest konieczne absolutnie. Jak Tomaszowa odpowiedź przyrównywała wieczne teraz do czasowego teraz, o ile rozważana była absolutna konieczność, o tyle przeciwna odpowiedź oddzielała wieczne teraz od czasowego teraz w tym ujęciu (Hughes 2002,156-157).

\section{Zakończenie}

Wracając ponownie do Listu do Bernarda, należy zwrócić uwagę na obecne w tym dziełku rozróżnienie, separujące ludzkie i Boże poznanie oraz rozumienie czasu. Jeśli człowiek rzeczy przeszłe pamięta, teraźniejsze rozpoznaje i próbuje zrozumieć a przyszłych się spodziewa i przewiduje (cyceroniańska triada), to w Bogu, zgodnie z kategoriami których używa Akwinata, nie ma żadnego ruchu i żadnej zmiany, a czas jest teraźniejszością w której wszystkie rzeczy są dla Niego obecne. Żadne określenie czasowe nie powinno wiązać i ograniczać Bożej wszechmocy czy też opatrzności (Brzózy 2000, s. 47). Akwinata pisze w Liście: „Tak jednak jak Bóg jest wolny od wszelkiego ruchu, zgodnie ze słowami Księgi Malachiasza $(3,6)$ : «Ja Pan nie odmieniam się», tak też przekracza każde czasowe następstwo. Nie znajduje się w Nim ani przeszłość, ani przyszłość, lecz wszystkie rzeczy przyszłe i przeszłe są dla Niego obecne w teraźniejszości, tak jak sam powiedział Mojżeszowi, swojemu słudze: «Jestem, który jestem» (Wj 3, 14)" (Tomasz z Akwinu 2014, 19). Myśl Tomaszowa, w której prostota Boga jest kluczem do wielu zagadnień, w wyraźny sposób sygnalizuje tożsamość zarówno atrybutów Bożych z samą istotą Boga jak i ze sobą. Brak jakiejkolwiek zmiany i ruchu oznacza brak zmiany w Jego wiedzy, w Jego woli i decyzjach określanych mianem opatrzności. Śmierć człowieka, która dokona się w przyszłości, pozostaje rzeczą przygodną, a więc jako ta, która może dokonać się w każdym czasie, nie jest determinowana wiedzą Boga. Ale nie jest jednocześnie tak, że Bóg o tym nie wie, czy też, że Jego wiedza nie sięgając tej sfery życia ludzkiego, jaką jest śmierć i cierpienie, się nie realizuje.

Prezentowane uwagi czołowych tomistów piszących w nurcie analitycznym, wpisują się w zagadnienia poruszane przez Akwinatę w ostatnim 
podyktowanym przez siebie dziele. Problem opatrzności jest przez nich podejmowany w różnoraki sposób - w zależności od bardziej fundamentalnych założeń, a także zastosowanych metod. Dla B. Daviesa takim założeniem - punktem odniesienia jest kategoria dobra, która jego zdaniem przenika myśl Tomaszową, w tym zarówno opis natury Boga, jak i rzeczywistości stworzonej. Temat cierpienia, który podjęła w swoich pracach E. Stump, naprowadza na bogate Tomaszowe rozumienie opatrzności, pozwala odczytać jego celowość. Analizy S.L. Brocka i Ch. Hughesa dotykają już wprost odniesienia wiedzy i opatrzności Bożej do przyszłych przygodnych wydarzeń. Ich uwagi o tyle są cenne, że we współczesnej dyskusji na zarysowane tematy, prezentują stanowisko Tomaszowe względem popularnego i „odświeżonego” molinizmu czy też teizmu otwartego. W przypadku Ch. Hughesa, gdy bierze on pod uwagę same argumenty, pozwala sobie na odchodzenie od myśli Tomaszowej i formułowanie wniosków nie zawsze zgodnych z samą myślą Tomasza (autor zasadniczo zaznaczał te miejsca). Oczywiście trudno jest mówić o faktycznym rozwijaniu tej problematyki, a więc i „nowym odczytaniu Tomasza”, skoro i tak ramy pozostawione po nim pozostają nietknięte. Raczej zyskujemy ponowne zainteresowanie dawną problematyką, zyskujemy nowy wiatr, by ćwiczyć się w języku mądrości pozostawionym po Akwinacie, który mimo wszystko nadal pozostaje naszym, a nie Boskim sposobem mówienia.

\section{Bibliografia}

Anscombe, Gertrude Elizabeth Margaret. 1981. Arystoteles. In: G. E. M. Anscombe, P. T. Geach, Trzej filozofowie. Warszawa: PAX: 19-88.

Brock, Stephen Louis. 2006. G.E.M. Anscombe and Thomas Aquinas on Necessity and Contradiction in Temporal Events. In: Analytical Thomism, edited by C. Peterson, et M.S. Pugh, 283-302. Hampshire: Ashgate.

Brzózy, Zbigniew Nikodem. 2000. O Bożej przedwiedzy i przyszłych zdarzeniach. Zagadnienie «futura contingentia» na podstawie Komentarza Tomasza z Akwinu do «Hermeneutyki» Arystotelesa. Poznań: Wydawnictwo UAM.

Davies, Brian. 1992. The Thought of Thomas Aquinas. Oxford: Oxford University Press. 
Davies, Brian. 2011. Thomas Aquinas on God and Evil. Oxford - New York: Oxford University Press.

Gałaj, Andrzej. 2012. Udręka predestynacji. Nowe spojrzenie na teorię poznania Bożego św. Tomasza z Akwinu. Warszawa: Studio Beta.

Grzegorz Wielki. 2007. Moralia. Komentarz do Księgi Hioba XVI, 10, tłum. S. Naskręt, E. Buszewicz, K. Nastał, L. Gładyszewski, t. 3. Kraków: Wydawnictwo Benedyktynów „Tyniec”.

Hughes, Christopher. 2002. Aquinas on God's Knowledge and Future Contingens. In: Mind, Metaphysics and Value in the Thomistic and Analytical Traditions, edited by J. Haldane, 143-159. Notre Dame: University of Notre Dame Press.

Łukasiewicz, Dariusz. 2014. Opatrzność Boża, wolność, przypadek. Studium z analitycznej filozofii religii. Kraków: „W drodze”.

Olszewski, Mikołaj. 2001. Komentarz do Kwestii 14. In: Tomasz z Akwinu, Traktat o Bogu. Summa teologii, kwestie 1-26, 638-680. Kraków: Znak.

Paluch, Michał. 2003. „Note sur les distinctions entre les nécessités chez Thomas d'Aquin." Archives d'histoire doctrinale et littéraire du Moyen Âge 1 (2003) 70 : 219-231.

Roszak, Piotr. 2013. „Żyć w cieniu pytań. Antropologiczne przesłanie Expositio super Iob św. Tomasza z Akwinu.” Biblica et Patristica Thoruniensia 6: 111-134.

Stump, Eleonore. 2003. Aquinas. London: Routledge.

Stump, Eleonore. 2012. Providence and the Problem of Evil. In: The Oxford Handbook to Aquinas, edited by B. Davies, E. Stump, 401-417. Oxford - New York: Oxford University Press.

Tkaczyk, Michał. 2015. Futura contingentia. Lublin: Wydawnictwo KUL.

Tomasz z Akwinu. 2013. Komentarz do „Hermeneutyki” Arystotelesa, tłum. A. P. Stefańczyk. Lublin: Polskie Towarzystwo Tomasza z Akwinu.

Tomasz z Akwinu. 2014. List do Bernarda (Epistola ad Bernardum). In: „Opera Philosophorum Medii Aevi”, t. 9, fasc. 4, 16-20. Warszawa, Wydawnictwo UKSW.

Torrell, Jean-Pierre. 2008. Tomasz z Akwinu - człowiek i dzieło, tłum. A. Kuryś. Kęty-Warszawa: Wydawnictwo Derewiecki.

Zembrzuski, Michał. 2014. „Ostatnie słowo Tomasza z Akwinu - problematyka filozoficzna i teologiczna «Listu do Bernarda»." In: Opera Philosophorum Medii Aevi, t. 9, fasc. 4, 9-15. Warszawa: Wydawnictwo UKSW. 